PENAMBAHAN INCENTIVE SPIROMETRY PADA DEEP BREATHING EXERCISE TERHADAP PENINGKATAN KAPASITAS FUNGSI PARU PADA PASIEN PASCAOPERASI JANTUNG DI RUMAH SAKIT JANTUNG HARAPAN KITA

\title{
Santoso $^{1}$, I Dewa Putu Sutjana ${ }^{2}$, Moh Ali Imron ${ }^{3}$, I Made Muliarta ${ }^{4}$, I Nyoman Adiputra ${ }^{5}$, Ni Nyoman Ayu Dewi ${ }^{6}$
}

\author{
${ }^{1}$ Program studi Magister fisiologi keolahragaan Universitas Udayana, Denpasar \\ ${ }^{2,4,5,6}$ Ilmu Faal, Fakultas Kedokteran Universitas Udayana, Denpasar \\ ${ }^{3}$ Program Studi Fisioterapi Aisyah Yogjakarta \\ ${ }^{6}$ Departemen Biokimia Fakultas Kedokteran Universitas Udayana, Denpasar
}

\section{E-Mail: sent2san@gmail.com}

\begin{abstract}
Abstrak
Pendahuluan: Penurunan fungsi paru merupakan masalah besar pada pasien pascaoperasi jantung. Berbagai teknik latihan napas telah dikembangkan fisioterapi di antaranya deep breathing exercie (DBE), namun teknik ini tidak memberikan informasi volume inspirasi saat latihan. Untuk mengatasi kelemahan latihan DBE maka ditambahkanlah program incentive spirometry.Tujuan penelitian untuk membuktikan penambahan latihan IS pada DBE lebih baik dalam meningkatkan FVC dan FEV1 pada pasien pascaoperasi jantung dibanding hanya DBE. Material dan metode: Penelitian ini menggunakan rancangan eksperimental dengan rancangan pretest-posttest control group design. Jumlah sampel penelitian 22 orang dan terbagi ke dalam dua kelompok. Kelompok Perlakuan 1 (KP1) mendapat perlakuan DBE, sedangkan Kelompok Perlakuan 2 (KP2) mendapat perlakuan IS dan DBE. Pengukuran FVC dan FEV1 menggunakan spirometri. Masing-masing kelompok mendapat perlakuan sehari setelah pascaoperasi sampai pasien pulang rawat inap. Hasil penelitian: Dari program DBE pada KP1 terjadi peningkatan FVC dengan nilai rerata pre test 1,33 $\pm 0,41$ liter dan post test 1,74 $\pm 0,36$ lite, dimana $p<0,05$, demikian juga terdapat peningkatan

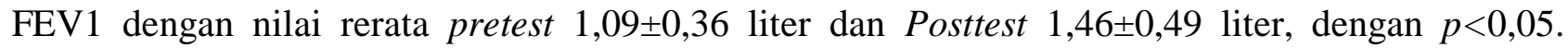
Sementara program DBE dan IS pada KP2 terjadi peningkatan FVC dengan nilai rerata pre test $1,12 \pm 0,39$ liter dan post test 1,84 $\pm 0,54$ liter, dengan nilai $p<0,05$. Demikian juga terjadi

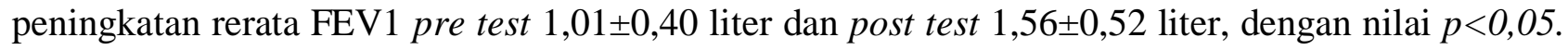
Perbedaan peningkatan FVC intervensi DBE pada KP1 dan IS+DBE pada KP2 1,74 \pm 049 liter dan 1,82 $\pm 0,54$ liter dengan nilai $p>0,05$. Rerata FEV1 setelah intervensi DBE pada KP1 1,46 $\pm 0,49$ liter, dan setelah intervensi DBE dan IS pada KP2 1,56 $\pm 0,52$ liter, dengan $p>0,05$. Perbedaan selisih peningkatan FVC pada tambahan IS + DBE dan DBE 0,7 liter dan 0,55 liter dan FEV1 0,41 liter dan 0,37 liter. Simpulan: Disimpulkan bahwa latihan antara IS+DBE dan DBE pada pasien pascaoperasi jantung sama-sama dapat meningkatkan FVC dan FEV1 secara bermakna, secara statistik selisih peningkatan FVC dan FEV1 antara IS+DBE dibanding DBE tidak bermakna.
\end{abstract}

Kata kunci : Kapasitas fungsi paru, incentive spirometry (IS), deep breathing exercise (DBE), FVC, FEV1 


\title{
ADDITIONAL INCENTIVE SPIROMETRY ON DEEP BREATHING EXERCISE INCREASE PULMONARY FUNCTION CAPACITY IN PATIENT WITH POST CARDIAC SURGERY IN THE HOSPITAL OF HEART AND VASCULAR HARAPAN KITA
}

\begin{abstract}
Introduction: Decreased lung function is main problem in post-cardiac surgery patients. Various breathing exercise techniques have been developed by physiotherapist including deep breathing exercise (DBE), but they can not determine how much volume inhalation. To overcome this, incentive spirometry (IS) was added. IS offers a dosage setting function that provide motivation throught visual feed back. This study was conducted to determine the effects of DBE and IS on improving pulmonary function in patients after cardiac surgery. Materiel and methode: This research metode is experimental using randomized pretest posttest control group design. Sample were taken from patients undergoing surgery in the hospital of Hearth and Vascular Harapan Kita. Respondents were divided into two groups randomly selected. Treatment group 1 given DBE intervention. Treatment group 2 given IS and DBE intervention. Every group consisted of 11 people. In both groups an evaluation of lung function capacity with spirometry was used assess FVC and FEV1. Every group given intervention 24 hours after operation to 4 days. Result: From the DBE program on group 1 there was in increase in FVC with a mean pretest value of $1.33 \pm 0,1$ liters and posttest $1.74 \pm 0.49$ liters, where $p<0.05$. Likewish there is in increase in FEV1 with a mean pretest value $1.09 \pm 0.36$ liters and post test $1.46 \pm 0,49$ liters, with $p<0.05$. While from the DBE and IS training program on group 2 there was an increase in FVC with an average pre test value of $1.12 \pm 0.39$ liters and Post test $1.84 \pm 0.54$ liters, with $p<0.05$. Likewise, there was an increase in the average value FEV1 pre test $1.01 \pm 0,40$ liters, with $p<0.05$. After the DBE program (post test) on group 1 the mean FVC was $1.74 \pm 0,49$ and $1.82 \pm 0.54$ liters in the Post test group 2 with the DBE+ IS program, with $p>0.05$. For the FEV1 posttest on group 1 there was an average of $1.46 \pm 0.49$ liters and in the FEV1 posttest on group 2 with a mean value of $1.56 \pm 0,52$ liters with $p=0.641$. In this study can be concluded that the addition of incentive spirometry plus deep breathing exercise training in post of cardiac patients can significanly increase FVC and FEV1 pulmonary function, there is no statistically significant difference between in addition IS + DBE and DBE.
\end{abstract}

Keyword: Pulmonary function capacity, incentive spirometry (IS), deep breathing exercise (DBE), FVC, FEV1

\section{PENDAHULUAN}

Penurunan volume dan kapasitas fungsi paru adalah masalah serius pada pasien pascaoperasi jantung. Force vital capacity berkurang hingga $70 \%$ setelah operasi dan tetap berkurang $35 \%$ pada saat tiga minggu pascaoperasi ${ }^{1}$. Penurunan volume dan kapasitas paru bisa mendasari adanya resiko komplikasi paru seperti atelektasis dan pneumonia $^{2}$.
Penanganan fisioterapi merupakan intervensi nonfarmakologis yang bertujuan untuk meningkatkan status kesehatan pasien pascaoperasi bedah jantung. Berbagai tujuan intervensi fisioterapi pada pasien pascaoperasi jantung adalah untuk mengembangkan torak guna meningkatkan volume dan kapasitas fungsi paru. Adanya penurunan volume paru pada pasien pascaoperasi jantung menjadi 
prioritas penting untuk mengembangkan fungsi paru. Namun sayangnya belum ada yang menyebutkan salah satu teknik fisioterapi tertentu lebih baik baik terhadap teknik fisioterapi lainnya.

Teknik fisioterapi yang dapat meningkatkan pengembangan paru seperti deep breathing exercise telah diberikan pada pasien pascaoperasi jantung, deep breathing exercise menekankan aktif inspirasi dan menahan napas beberapa detik sebelum ekspirasi pasif. Deep breathing exercise dilakukan untuk reekspansi paru yang colaps setelah operasi dan mobilisasi dahak. Namun, tidak semua pasien mudah untuk melakukan volume inspirasi yang tepat, dikarenakan tidak adanya parameter ukuran volume. Sehingga kedalaman napas yang tidak terukur akan menjadikan kurang konsisten dan tidak efektifnya latihan ${ }^{3}$.

Teknik lain untuk meningkatkan kapasitas fungsi paru pada pasien pascaoperasi jantung adalah dengan menggunakan incentive spirometry ${ }^{4}$. Incentive spirometry adalah teknik latihan napas yng dilakukan melalui alat yang dapat memberikan visual feed back inspired flow dan volume, adanya visual feed back akan meningkatkan teknik latihan bernapas dan motivasi pasien. Dengan teknik ini maka kemampuan peningkatan volume paru akan lebih besar. Latihan napas dengan incentive spirometry akan memberikan arahan volume inspirasi sehingga akan membantu memberikan dosis volume latihan yang tepat dan pasien akan lebih konsisiten terahadap latihan. sehingga latihan napas dengan incentive spirometry dapat memperbaiki kelemahan latihan dengan deep breathing. oleh karena itu perlu dilakukan penelitian untuk membuktikan pengaruh penambahan incentiive spirometry pada deep breathing terhadap pasien pascaoperasi.

\section{BAHAN DAN METODE PENELITIAN}

Penelitian ini menggunakan rancangan true experimental, dengan randomized pretest-posttest control group design yang dilakukan di Ruang rawat Rumah Sakit Jantung dan Pembuluh Darah Harapan Kita dari bulan April 2019 sampai dengan Mei 2019. Responden merupakan pasien yang telah terdiagnosis penyakit jantung oleh Dokter Penanggung Jawab Pasien (DPJP) yang tercatat pada rekam medik pasien dan direncakan operasi jantung. Sampel dibagi ke dalam dua kelompok yang dipilih dengan random alokasi. Kelompok Perlakuan 1 (KP1) terdiri dari 11 orang diberi latihan deep breathing exercise (DBE) dan Kelompok Perlakuan 2 (KP2) terdiri dari 11 orang diberi terapi incentive spirometry (IS) pada deep breathing exercise disebut dengan Kelompok Perlakuan 2 (KP2).

Pemeriksaan kapasitas fungsi paru (FVC dan FEV1) menggunakan spirometri. Intervensi diberikan selama 4 hari pascaoperasi jantung.

\section{HASIL PENELITIAN}

\section{Karakteristik Subjek Penelitian}

Tabel .1

Karakteristik subjek penelitian dan hasil uji homogenitas data

\begin{tabular}{lccc}
\hline \multirow{1}{*}{\multicolumn{1}{c}{ Variabel }} & $\begin{array}{c}K P 1 \\
(\mathrm{n}=11)\end{array}$ & $\begin{array}{c}\text { KP } 2 \\
(\mathrm{n}=11)\end{array}$ & $P$ \\
\cline { 2 - 4 } & Mean $\pm \mathrm{SD}$ & Mean $\pm \mathrm{SD}$ & \\
\hline Umur (tahun) & $52,91 \pm 6,67$ & $56,27 \pm 6,15$ & 0,842 \\
Ejection Fraction & $61,64 \pm 11,26$ & $59,82 \pm 8,94$ & 0,385 \\
$(\%)$ & $22,47 \pm 3,13$ & $27,20 \pm 5,28$ & 0,076 \\
BMI (kg / m $\left.{ }^{2}\right)$ & $159,82 \pm 9,68$ & $160,00 \pm 5,29$ & 0,02 \\
Tinggi Badan (cm) & $57,45 \pm 10,8$ & $69,27 \pm 11,47$ & 0,967 \\
Berat Badan (kg) & $8,47 \pm 5,40$ & $6,06 \pm 2,69$ & 0,42 \\
Ventilator time (jam) & $109,18 \pm 43,85$ & $92,00 \pm 51,38$ & 0,276 \\
CPB Time (menit) & & & \\
\hline
\end{tabular}




\section{Data Deskripsi Pengukuran FVC dan} FEV1

Tabel. 2

Data deskripsi hasil pengukuran FVC dan

FEV1

\begin{tabular}{|c|c|c|c|c|c|c|}
\hline & \multicolumn{3}{|c|}{ KELOMPOK } & \multicolumn{3}{c|}{ KELOMPOK } \\
\cline { 2 - 7 } & PERLAKUAN 1 (DBE) & PERLAKUAN 2 (DBE+IS) \\
\hline Min & Max & Mean \pm SD & Min & Max & Mean \pm SD \\
\hline $\begin{array}{c}\text { FVC (liter) } \\
\begin{array}{c}\text { PRE } \\
\text { Operasi }\end{array}\end{array}$ & 1,13 & 3,69 & $2,15 \pm 0,83$ & 1,12 & 3,69 & $2,23 \pm 0,77$ \\
\hline $\begin{array}{c}\text { Pre test } \\
\text { Post test }\end{array}$ & 0,75 & 2,13 & $1,33 \pm 0,41$ & 0,58 & 1,84 & $1,12 \pm 0,39$ \\
\hline FEV1 (liter) & 1,02 & 2,44 & $1,74 \pm 0,49$ & 1,21 & 3,18 & $1,82 \pm 0,54$ \\
\hline $\begin{array}{c}\text { PRE } \\
\text { Operasi }\end{array}$ & 1,01 & 3,19 & $1,81 \pm 0,65$ & 0,97 & 2,51 & $1,72 \pm 0,54$ \\
\hline Pre test & 0,56 & 1,8 & $1,09 \pm 0,36$ & 0,49 & 1,67 & $1,01 \pm 0,40$ \\
\hline \begin{tabular}{c} 
Post test \\
\hline
\end{tabular} & 0,82 & 2,39 & $1,46 \pm 0,49$ & 0,81 & 2,68 & $1,56 \pm 0,52$ \\
\hline
\end{tabular}

\section{Uji Normalitas dan Homogenitas}

Tabel. 3

Uji Normalitas dan Homogenitas

\begin{tabular}{ccccc}
\hline & \multicolumn{2}{c}{$\begin{array}{c}\text { Shapiro Wilk } \\
\text { Test }\end{array}$} & \multicolumn{2}{c}{ Levene's Test } \\
\cline { 2 - 5 } Kelompok & \multicolumn{2}{c}{$p$-value } & \multicolumn{2}{c}{$p$-value } \\
\cline { 2 - 5 } & Pre & Post & Pre & Post \\
\hline FVC & & & & \\
KP1 & 0,835 & 0,472 & 0,616 & 0,720 \\
KP2 & 0,627 & 0,040 & & \\
FEV1 & & & & \\
KP1 & 0,790 & 0,751 & 0,783 & 0,890 \\
KP2 & 0,267 & 0,526 & & \\
\hline
\end{tabular}

Berdasar hasil analisis yang disajikan pada Tabel 3 diatas, hanya nilai FVC post intervensi pada KP2 dengan nilai $p<0,05$ yang berarti tidak berdistribusi normal dan tidak homogen. Sedangkan untuk nilai $p$ lainnya berdistribusi normal dan varian data homogen.

Berdasarkan hasil analisa tersebut maka uji hipotesis 1 dan uji hipotesis II untuk FEV1 menggunakan uji parametrik yaitu Paired Sample t Test. Uji hipotesis II untuk
FVC menggunakan Wilcoxon Range Test dan Uji statistik FVC pada hipotesis III menggunakan uji nonparametrik yaitu Mann Whitney $U$ Test. Sedangkan uji hipotesis FEV1 pada hipotesis III menggunakan uji parametrik Independent $t$-Test.

\section{Uji Hipotesis 1}

Hasil uji rerata nilai FVC dan FEV1 sebelum dan setelah intervensi pada KP1 menggunakan uji paired T-Test yang disajikan dalam Tabel 4.

Tabel 4

Hasil uji beda nilai FVC dan FEV1 pada KP1

\begin{tabular}{lccc}
\hline \multirow{2}{*}{ Test Spirometry } & \multicolumn{2}{c}{ Mean \pm SD } & \multirow{2}{*}{$p$} \\
\cline { 2 - 3 } & Pre & Post & \\
\hline FVC (liter) & $1,33 \pm 0,41$ & $1,74 \pm 0,49$ & 0,019 \\
FEV1 (liter) & $1,09 \pm 0,36$ & $1,46 \pm 0,49$ & 0,010 \\
\hline
\end{tabular}

Berdasarkan hasil analisis yang tersaji pada Tabel 3. Diperoleh nilai $p$ uji beda FVC dan FEV1 $p<0,05$ pada KP1, yang menunjukkan bahwa intervensi deep breathing exercise pada pasien pascaoperasi jantung meningkatkan kapasitas fungsi paru FVC dan FEV1 secara signifikan.

\section{Uji Hipotesis II}

Hasil uji rerata nilai FVC sebelum dan setelah intervensi DBE dan IS menggunakan Uji Wilcoxon signed Rank Test, dan hasil uji rerata nilai FEV1 sebelum dan sesudah intervensi menggunakan uji Paired t-Test disajikan pada Tabel 5.

Tabel 5

Hasil uji beda nilai FVC dan FEV1 KP2

\begin{tabular}{lccc}
\hline Test & \multicolumn{2}{c}{ Mean \pm SD } & \multirow{2}{*}{ Ppirometry } \\
\cline { 2 - 3 } & Pre & Post & \\
\hline FVC (liter) & $1,12 \pm 0,39$ & $1,82 \pm 0,54$ & 0,003 \\
FEV1(lite) & $1,01 \pm 0,40$ & $1,56 \pm 0,52$ & 0,002 \\
\hline
\end{tabular}


Berdasarkan hasil analisisi yang tersaji pada Tabel 4, terdapat hasil uji beda pada FVC dan FEV1 $p<0,05$. Hasil ini menunjukkan bahwa penambahan latihan DBE dan IS pada pasien pascaoperasi jantung meningkatkan kapasitas fungsi paru (FVC dan FEV1) secara signifikan.

\section{Uji Hipotesis III}

Hasil uji beda nilai rerata FEV1 sebelum dan sesudah intervensi antara KP1 dan KP2 menggunakan uji Independent $t$ Test. dan hasil uji beda FVC sebelum dan sesudah intervensi antara KP1 dan KP2 menggunakan Mann Whitney U-Test. Disajikan pada Tabel 6.

Tabel 6

Hasil uji Beda Nilai FVC pada KP1 dan KP2

\begin{tabular}{cccc}
\hline & \multicolumn{3}{c}{ Mean \pm SD } \\
\cline { 2 - 4 } Kelompok & \multicolumn{2}{c}{ FVC (liter) } \\
\cline { 2 - 4 } & Pre Test & Post test & Selisih \\
\hline KP 1 & $1,33 \pm 0,41$ & $1,74 \pm 0,49$ & $0,41 \pm 0,48$ \\
KP 2 & $1,12 \pm 0,39$ & $1,82 \pm 0,54$ & $0,70 \pm 0,40$ \\
\multicolumn{1}{c}{$p$} & 0,228 & 1,000 & 0,217 \\
\hline
\end{tabular}

Tabel 7

Hasil Uji Beda Nilai FEV1 pada KP1 dan KP2

\begin{tabular}{cccc}
\hline & \multicolumn{3}{c}{ KP2 } \\
\cline { 2 - 4 } Kelompok $\pm \mathrm{SD}$ \\
\cline { 2 - 4 } & \multicolumn{2}{c}{ FEV1 (liter) } \\
\cline { 2 - 4 } & Pre Test & Post test & Selisih \\
\hline KP 1 & $1,09 \pm 0,36$ & $1,46 \pm 0,49$ & $0,37 \pm 0,38$ \\
KP 2 & $1,01 \pm 0,40$ & $1,56 \pm 0,52$ & $0,55 \pm 0,45$ \\
$P$ & 0,607 & 0,641 & 0,217 \\
\hline
\end{tabular}

Berdasarkan hasil analisis yang tersaji pada Tabel 6 dan Tabel 7 didapatkan uji beda kapasitas fungsi paru (FVC dan FEV1) setelah intervensi DBE pada KP1 dan DBE+IS pada KP2 didapatkan $p>0,05$. Dari hasil analisis statistik ini dapat disimpulkan bahwa perbedaan peningkatan fungsi paru (FVC dan FEV1) tidak bermakna antara kelompok pasien yang diberikan intervensi IS+DBE dan DBE pada pasien pascaoperasi jantung.

\section{PEMBAHASAN}

\section{Karakteristik subjek penelitian}

Jumlah keseluruhan subjek yang mengikuti penelitian sampai akhir adalah 22 subjek. Sebanyak 68,2\% adalah laki-laki atau berjumlah 15 orang. Sedangkan sisanya sebesar $31,8 \%$ adalah perempuan atau berjumlah 7 orang. Rerata subjek pada penelitian ini berusia $54 \pm 6,84$ tahun. Pada penelitian ini terdapat subjek yang menjalani by pass graft adalah 40,9\% atau sebanyak 9 orang sedangkan subjek yang menjalani operasi ganti katup mendominasi sebanyak $45,5 \%$. Rerata indeks masa tubuh pada KP 2 $27,2 \pm 53 \mathrm{~kg} / \mathrm{m} 2$. BMI mempengaruhi komplikasi paru dan proses pemulihan pascaoperasi ${ }^{5}$.

Karakteristik subjek penelitian pada kedua kelompok perlakuan memiliki varian data yang homogen.

\section{Pengaruh operasi terhadap FVC dan FEV1 pada kedua kelompok}

Komplikasi paru pada pasien pascaopearasi jantung merupakan masalah klinis serius. Gangguan pernapasan disebabkan oleh berbagai faktor, seperti terkait adanya komorbiditas, fungsi paru praoperasi, durasi penggunaan ventilator dan $C P B$ times serta jenis dan durasi prosedur operasi. Selain itu, anestesi umum telah terbukti mengurangi kapasitas residual fungsional sebesar $20 \%$, dan pasien yang menjalani penggantian graft dari arteria mammaria telah terbukti memiliki resiko efusi pleura dan masalah paru lebih tinggi ${ }^{6}$.

Terdapat rerata fungsi paru FVC dan FEV1, untuk rerata FVC pada KP1 dari $2,15 \pm 0,83$ liter menjadi $1,33 \pm 0,41$ liter, dengan $\mathrm{p}=0,004$, sedangkan FVC KP2 dari $2,23 \pm 0,77$ liter menjadi $1,12 \pm 0,39$ liter, 
dengan $\mathrm{p}<0,05$, untuk FEV1 KP1 1,81 $\pm 0,65$ liter menjadi $1,09 \pm 0,36$ liter, dengan $p=0,008$. Pada uji beda sebelum operasi dan setelah operasi terdapat penurunan fungsi paru yang signifikan dengan $p<0,05$. Sesuai dengan penelitin lain terjadi penurunan fungsi paru yang signifikan pada pasien pascaoperasi jantung ${ }^{7}$.

\section{Efek latihan deep breathing exercise terhadap nilai FVC dan FEV1}

Salah satu tujuan penetian ini adalah untuk mengetahui efek latihan DBE terhadap FVC dan FEV1 berdasarkan hasil penelitian ini KP1 yang diberikan latihan DBE mampu meningkatkan FVC dan FEV secara signifikan dengan nilai $\mathrm{p}<0,05$.

Komplikasi pascaoperasi terjadi penurunan kapasitas paru dan pengembangan disfragma akibat adanya nyeri luka operasi, pengaruh luka operasi, pengaruh anestesi akan menyebabkan pernapasan yang dangkal yang menurunnkan ventilasi pada regio paru yang dependent. Deep breathing exercise dilakukan dengan inspiraasi yang dalam, panjang dan perlahan yang dapat mempengaruhi distribusi udara terrutama pada saluran pernapasan yang dependent ${ }^{8}$. Latihan DBE pascaoperasi berguna untuk mengatasi gangguan paru yang timbul selama operasi dan mencegah kemunduran fungsi paru lebih lanjut. Beberapa penelitian, DBE pada awal pascaoperasi jantung mampu memperbaiki fungsi secara signifikan ${ }^{9}$. Teknik latihan DBE merupakan latihan dengan inspirasi aktif yang dikombinasi dengan menahan napas selama beberapa detik (2-5 detik), latihan ini mampu meningkatkan inspirasi maksimal sebelum ekspirasi. Inspirasi maksimal dengan menahan napas akan mampu mengurangi terjadinya colapse pada paru dan mengatasi atelektasis. Dengan latihan inspirasi dan ekspirasi yang maksimal juga akan melatih kekuatan otot-otot diafragma. Kekuatan otototot inspirasi dan distribusi udara akan meningkatkan volume dan tekanan intrapleura dan intra alveolar ${ }^{10}$.
Volume paru yang meningkat setelah inspirasi maksimal akan mampu meningkatkan jumlah udara yang akan dikeluarkan secara paksa setelah inspirasi maksimal, sehingga FVC dan FEV1 akan meningkat. Manzano dan kawan kawan menemukan deep breathing mampu meningkatkan perbaikan mekanik paru yang akan memberikan efek Force vital capacity ${ }^{11}$.

\section{Efek penambahan incentive spirometry dan deep breathing exercise terhadap nilai FVC dan FEV1}

Latihan deep breathing exercise dan incentive spirometry yang diberikan pada pasien pascaoperasi jantung dapat meningkatkan fungsi paru secara bermakna. Dengan adanya feed back aliran dan volume udara yang ter-visualisasi pada alat akan mampu meningkatkan motivasi pasien untuk lebih mamaksimalkan inspirasi. Pasien akan mampu melakukan dosis volume inspirasi yang konsisten dan selalu bisa ditingkatkan ${ }^{12}$.

Program latihan pernapasan yang menggunakan incentive spirometry dan deep breathing exercise dapat memberikan latihan tahanan otot inspirasi. Ke dua teknik latihan dengan bernapas secara mendalam, perlahan dan panjang. Perbedaan latihan dengan incentive spirometry mampu memberikan visual feed back, arah dan gerakan inspirasi yang dapat yang dapat dikontrol melalui piston. Latihan pernapasan dengan incentive spirometry dapat memberikan stimulasi diafragma secara signifikan untuk meningkatkan volume tidal, volume cadangan inspirasi dan kapasitas inspirasi ${ }^{13}$.

Volume paru yang meningkat setelah inspirasi maksimal akan mampu meningkatkan jumlah udara yang dapat di keluarkan secara paksa setelah inspirasi maksimal, sehingga FVC dan FEV1 meningkat. pada penelitian Toshiaki tahun 2015 subjek yang diberikan latihan incentive spirometry terjadi peningkatan gerakan diafragma sebelum latihan $55,7 \pm 9,6 \mathrm{~mm}$ menjadi $63,4 \pm 10,2 \mathrm{~mm}$ dengan nilai $\mathrm{p}=0,041$ 
dan peningkatan gerakan dinding dada sebelum latihan $15,6 \pm 6,1 \mathrm{~mm}$ menjadi $23,4 \pm 10,4$ dengan nilai $\mathrm{p}=0,041$ vital capacity meningkat dari $3,6 \pm 0,8$ liter dengan nilai $\mathrm{p}=0,023$ liter.

\section{Efek peningkatan FVC dan FEV1 pada latihan kombinasi incentive spirometry dan deep breathing exercise dibanding dengan deep breathing exercise}

Berdasarkan hasil uji FVC dan FEV1 sesudah intervensi DBE pada KP1 dan DBE+IS pada KP2 didapatkan nilai p>0,005. Pasien pascaoperasi jantung yang diberikan latihan IS+DBE tidak lebih meningkatkan fungsi paru (FVC dan FEV1) dibanding dengan pasien yang diberikan latihan DBE. Hal ini sesuai dengan Sabirin, 2018 bahwa tidak ada perbedaan kapasitas fungsi paru yang signifikan antara kelompok yang diberikan IS+DBE dan DBE pada pasien pascaoperasi jantung pada fase pertama ${ }^{14}$.

Meskipun secara statistik tidak terdapat pengaruh perbedaan peningkatan FVC dan FEV1 yang signifikan di antara ke dua kelompok, namun terdapat perbedaan selisih yang menunjukkan bahwa tambahan IS+DBE cenderung lebih baik (dengan selisih peningkatan sebesar 0,7 liter dan 0,55 liter) dari pada DBE (dengan selisih 0,41 liter dan 0,37 liter) dalam meningkatkan fungsi paru FVC dan FEV1. Sebagaimana Gambar 1 .

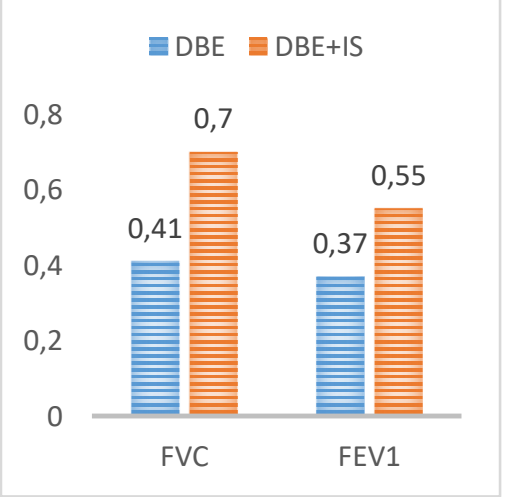

Gambar 1 Perbedaan selisi FVC dan FEV1 antara Dbe dan IS+ DBE
Latihan incentive spirometry dan deep breathing exercise ke duanya memberikan peningkatan inspirasi. Peningkatan kemampuan inspirasi pada ke dua teknik ini terjadi karena adanya kemampuan otot diafragma untuk berkontraksi dan distribusi udara sampai bagian paru dependent. Pada latihan dengan incentive spirometry adanya pengaruh tahanan piston saat inspirasi dan visual feedback akan lebih meningkatkan kemampuan otot-otot diafragma Pada latihan dengan incentive spirometry adanya tahanan piston dan visual feedback saat inspirasi akan memberikan tambahan motivasi dan kekuatan otot-otot pernapasan melakukan inspirasi yang lebih dalam. Saat inspirasi subjek diinstruksikan untuk meningkatkan kekuatan dengan mengusahakan agar indikator piston bergerak setinggi-tingginya sesuai kemampuan maksimal subjek. Pada keadaan ini akan tercapai volume maksimal. Indikator piston lain harus berada pada posisi tertentu dan subjek mempertahankan volume semaksimal mungkin. Kekuatan otot-otot inspirasi yang meningkat, terutama otot diafragma akan mempengaruhi volume dan tekanan intra pleural dan intra alveolar melalui perubahan volume dan tekanan intrathorak ${ }^{10}$. Penambahan visual feedback, adanya plate dan piston yang diberikan incentive spirometry mampu memberikan pengaturan dosis yang tepat yang tidak bisa diberikan pada latihan deep breathing. Penambahan teknik incentive spirometry akan mampu memberikan efek yang lebih pada kapasitas fungsi paru.

Evaluasi fungsi paru pada akhir sesi penelitian belum menunjukkna efek peningkatan yang signifikan, namun pada penelitian ini ditunjukkan adanya kecenderungan peningkatan kapasitas fungsi paru. Pada Gambar 2 dan Gambar 3 ditunjukkan adanya pertemuan garis fungsi paru, pada teknik deep breathing dan incentive spirometry mampu melampaui teknik latihan tunggal deep breathing. 


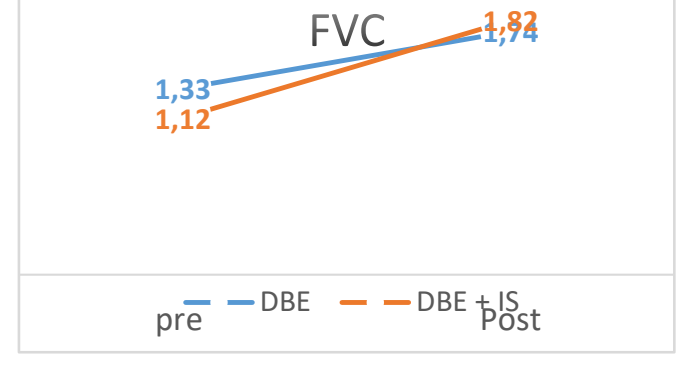

Gambar 2 Perbedaan FVC pretest dan Posttest

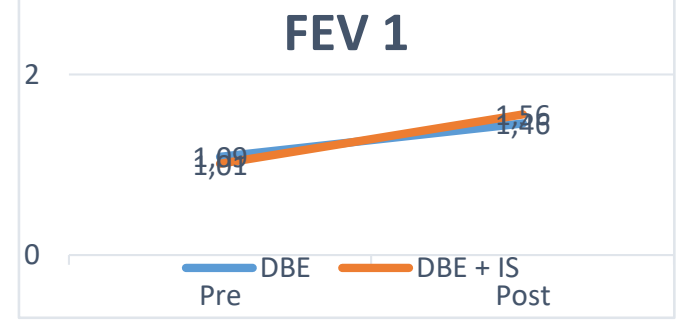

Gambar 3 Perbedaan FEV1 pre test dan Post test

Efek kombinasi intervensi incentive spirometry dan deep breathing exercise memiliki kelebihan untuk meningkatkan kapasitas fungsi paru bila dibanding dengan dengan intervensi tunggal, tetapi terdapat beberapa faktor internal dan external yang mempengaruhi. Keberhasilan aplikasi IS dan DBE terhadap peningkatan fungsi paru dibanding intervensi DBE pada pasien pascaoperasi jantung di Rumah Sakit Jantung dan Pembuluh Darah Harapan Kita belum tampak perbedaan peningkatan yang bermakna.

Meskipun IS memberikan tambahan visual feedback untuk mengatasi kelemahan teknik DBE, berbagai faktor yang bisa mempengaruhi latihan sehingga menyebabkan fungsi paru pada IS dan DBE belum meningkat secara signifikan dibanding hanya DBE. Beberapa faktor tersebut di antarannya faktor psikologis dan teknis. Faktor teknis adanya waktu intervensi yang pendek. Faktor psikologis seperti keluhan nyeri pascaoperasi sangat mempengaruhi terhadap program latihan dan evaluasi. Pascaoperasi jantung dengan incisi sternotomy, mengakibatkan keluhan sakit sampai beberapa minggu pascaoperasi, sehingga sampai hari ke empat subjek tidak maksimal melakukan evaluasi spirometri. Meskipun sudah diinformasikan akan keamanan jahitan operasi namun ratarata subjek masih khawatir untuk melakukan inspirasi dan ekspirasi maksimal saat tes spirometri. Pasien dengan keluhan nyeri saat mobilisasi memiliki kecenderungan penurunan volume paru yang lebih besar ${ }^{15}$.

Adanya rerata body mass index (BMI) pada KP2 27,20 $\pm 5,28 \mathrm{~kg} / \mathrm{m}^{2}$. sedikit lebih tinggi bila dibanding KP1 22,47 $\pm 3,13 \mathrm{~kg} / \mathrm{m}^{2}$. Pasien dengan BMI yang lebih tinggi cenderung memiliki resiko gangguan penurunan volume paru pada pasien pascabedah $^{14}$. Pada KP2 pasien operasi CABG lebih mendominasi, berdasarkan Cristina, 2011 menyebutkan terjadi penurunan kapasitas residu $20 \%$ pada pasien yang menjalani pengambilan graft dari artery mammaria untuk mengganti graft di coroner karena lebih besar memiliki resiko efusi pleura dan problem paru.

Rumah sakit memiliki standar clinical pathway pasien pascaoperasi jantung. Pasien pascaoperasi yang tidak memiliki komplikasi dan sudah mampu melakukan aktifitas jalan mandiri akan dipulangkan. Rata-rata pasien pulang dari rawat operasi jantung pada hari ke empat sampai hari ke enam. Adanya clinical pathway operasi jantung yang pendek tersebut tidak cukup memberikan pengaruh perbedaan peningkatan fungsi paru yang bermakna. Tidak ada perbedaan nilai rerata yang signifikan antara pasien yang diberikan IS dan DBE dengan pasien DBE saja untuk pasien pascaoperasi jantung sampai hari ke enam ${ }^{16}$.

\section{KETERBATASAN PENELITIAN}

1. Masa rawat inap pasien pascaoperasi singkat sehingga efek teraputik dengan waktu pemberian intervensi belum menunjukkan perbedaan peningkatan yang mencolok.

2. Saat melakukan uji spirometri subjek masih ada kekhawatiran terlepas jahitan sehingga subjek tidak melakukan evaluasi secara maksimal. 


\section{SIMPULAN}

Berdasarkan uraian dari hasil penelitian dan pembahasan pada bab sebelumnya, maka simpulan dari penelitian ini adalah sebagai berikut:

1. Latihan deep breathing exercise pada pasien pascaoperasi jantung. dapat meningkatkan kapasitas fungsi paru (FVC dan FEV1).

2. Latihan incentive spirometry dan deep breathing exercise pada pasien pascaoperasi jantung dapat meningkatkan kapasitas fungsi paru (FVC dan FEV1).

3. Tidak ada perbedaan yang bermakna antara latihan incentive spirometry dan deep breathing exercise dalam meningkatkan kapasitas fungsi paru pada pasien pascaoperasi jantung.

\section{SARAN} adalah:

Adapun saran yang dapat diberikan

1. Disarankan melakukan penelitian lanjutan dengan menggunakan waktu yang lebih panjang.

2. Penelitian ini dapat dilanjutkan pada saat pasien menjalani kelanjutan rawat jalan.

3. Disarankan berkolaborasi dengan dokter untuk menurunkan nyeri pada saat dilakukan evaluasi spirometri sehingga hasil tes tidak terlalu dipengaruhi oleh nyeri.

\section{DAFTAR PUSTAKA}

1. Moreno. 2011. Longitudinal evaluation the pulmonary function of the pre and postoperative periods in the coronary artery bypass graft surgery of patients treated with a physiotherapy protocol. Journal of Cardiothoracic Surgery, 6:62

2. Romanini W., Muller AP., Carvalho KA., Olandoski M, Faria-Neto JR, Mendes FL/2007. The effects of intermittent positive pressure and incentive spirometry in the postoperative of myocardial revascularization. Arq Bras Cardiol. 2007;89(2):94-9, 105-10

3. Agostini, P., Naidu, B. 2013. Effectiveness of Incentive Spirometry in Patients Following Thoracotomy and Lung Resection Including those at High Risk For Developing Pulmonary Complications. Thorax; 68:580-585

4. Diaz, C.M., Vieira, R.O., Oliveira, J.F., Lopes, A.J., Menexes, S.L., Guimaraes, F.S. 2011. Three Physiotherapy Protocols: Effects on Pulmonary Volumes after Cardiac Surgery. J Bras Pneumol:37:54-60

5. Aldenkortt, M., Lysakowski, C., Elia, N., Brochard, L., Tramer, M.R. 2012. Ventilation strategies in obese patients undergoing surgery: a quantitative systematic review and meta-analysis. Br J Anaesth;109:493- 502

6. Romanini W, Muller AP, Carvalho KA, Olandoski M, Faria-Neto JR, Mendes FL, et al. The effects of intermittent positive pressure and incentive spirometry in the postoperative of myocardial revascularization. Arq Bras Cardiology. 2007;89(2):94-9, 105-10

7. Renault JA., Costa-Val R., Rosseti MB., Houri Neto M. Comparison between deep breathing exercises and incentive spirometry after CABG surgery. Rev Bras Ciiculation Cardiovascular. 2009; 24(2):165-72

8. Grams,. Ono. "Breathing exercises in upper abdominal surgery: a systematic review and meta-analysis," Brazilian Journal of Physical Therapy, vol. 16, no. 5, pp. 345-353, 2012

9. Haeffener, M.P., Ferreira, G.M., Barreto, S.S., Arena, R., Dall'Ago, P. 2008. Incentive Spirometry With Expiratory Positive Airway Pressure Reduces Pulmonary Complications, Improves Pulmonary Function and 6Minute Walk Distance in Patients Undergoing Coronary Artery Bypass Graft Surgery. Am Heart J;156. 900 e1-900.e8. 
10. Terry-Des, J. 2008. Cardiopulmonary Anatomy And Physiology Essetial Of Respiratory Care. Delmar Cengage Learning. Fifth Edition.

11. Manzano.,C., De Carvalho., SaraivaRomanholo., and J. E. Vieira. "Chest physiotherapy during immediate postoperative period among patients undergoing upper abdominal surgery: Randomized clinical trial," Sao Paulo Medical Journal, vol. 126, no. 5, pp. 269-273, 2008.

12. Freitas ER., Soares BG., Cardoso JR., Atallah AN. Incentive spirometry for preventing pulmonary complications after coronary artery bypass graft. Cochrane Database System Review 2012;9:CD004466.

13. Seo KC.The Effect of Pulmonary Function and Respiratory Muscle Activity in the Stroke Patients after Complex Breathing Exercise. Doctorial thesis, Graduate School of Daegu University. 2012, pp 16-20

14. Sabirin B..Indra A, 2018. .Incentive spirometry and deep breathing exercise prefer to prevent decreased of lung vital capasity As good as deep breathing exercise post Coronary artery bypass graft phase I. Jurnal Keperawatan fisioterapi. Program Studi Fisioterapi Fakultas

Keperawatan dan Fisioterapi Institut Kesehatan Medistra, Lubuk Pakam

15. Freitas ER., Soares BG., Cardoso JR., Atallah AN. Incentive spirometry for preventing pulmonary complications after coronary artery bypass graft. Cochrane Database System Review 2012;9:CD004466

16. Charlotte, U., Margareta., Hanset. 2011. Deep Breathing Exercises with Positive Expiratory Pressure at a Higher Rate Improve Oxygenation in the Early Period after Cardiac Surgery - a randomised controlled trial. European Journal of Cardio-thoracic Surgery; $40: 162-167$

17. Sabirin B..Indra A, 2018. .Incentive spirometry and deep breathing exercise prefer to prevent decreased of lung vital capasity As good as deep breathing exercise post Coronary artery bypass graft phase I. Jurnal Keperawatan fisioterapi. Program Studi Fisioterapi Fakultas Keperawatan dan Fisioterapi Institut Kesehatan Medistra, Lubuk Pakam

18. Freitas ER., Soares BG., Cardoso JR., Atallah AN. Incentive spirometry for preventing pulmonary complications after coronary artery bypass graft. Cochrane Database System Review 2012;9:CD004466

19. Charlotte, U., Margareta., Hanset. 2011. Deep Breathing Exercises with Positive Expiratory Pressure at a Higher Rate Improve Oxygenation in the Early Period after Cardiac Surgery - a randomised controlled trial. European Journal of Cardio-thoracic Surgery; 40 : $162-1$ 